\title{
Exploring Users Motivation in Innovation Communities
}

\author{
Anna Ståhlbröst* \\ Social Informatics \\ Luleå University of Technology \\ SE-971 87 Luleå, Sweden \\ Fax: +46920492849 \\ E-mail: anna.stahlbrost@ltu.se \\ * Corresponding author
}

\section{Birgitta Bergvall-Kåreborn}

\author{
Social Informatics \\ Luleå University of Technology \\ SE-971 87 Luleå Sweden \\ Fax: +469204928 49 \\ E-mail: birgitta.bergvall-kareborn@ltu.se
}

\begin{abstract}
A rapid growth of technologies supporting user interaction on the Internet, such as social networking sites and other virtual communities, can be seen today. These virtual communities have been shown to be of great value to companies that want to involve users in their innovation processes. However, in order to guide organisations on how to utilise their innovation intermediary communities, more knowledge is needed regarding who they are and their motivational drivers for participating in a community. The aim of this paper therefore is to explore who the users are and what motivates them to contribute to innovation processes in an innovation intermediary community. The main findings of our study indicate that users' motivation to participate is influenced by community type as well as technology adoption type. This study show that in innovation intermediary communities, one important motivational factor for users is learning.
\end{abstract}

Keywords: Open Innovation; User Involvement; Innovation Communities; User Characteristics, User Driven Innovation; Motivation; Botnia Living Lab; Technology Adoption Type; Innovation Intermediary Community

Biographical Notes: Anna Ståhlbröst is a researcher at Luleå University of Technology, Sweden. Her research is focused on Living Lab and open user driven innovation processes, with special interest in users' motivators.

Birgitta Bergvall-Kåreborn is professor in Social Informatics at Luleå University of Technology. Her research interest is focused on toolkits for codevelopment of innovations in distributed and open innovation milieus. 


\section{Introduction}

We can see a rapid growth today of technologies supporting user interaction on the Internet, such as social networking sites and other virtual communities. These communication tools offer people new and varied ways to communicate and influence both through their PC and their mobile phone. This offers a wealth of possibilities for companies that want to involve users in their innovation processes. In these virtual communities, users both produce and consume information in a voluntary and democratic manner, which makes it possible for strangers to get aid in problem solving activities (Lampel and Bhalla, 2007). These communities also are shown to be of great value, as they produce products and services which can compete with manufactured products; hence, the communities not only exist, they also triumph (von Hippel, 2001).

A vast flora of innovation communities is available on the Internet. Some of them are focusing on supporting open source development projects, while others are more focused on involving users in developing a specific brand's products. Hence, these different types of innovation communities can be clustered in many different ways; in this paper, we have chosen to cluster them into five different types according to users' activities in the communities and its scope. These five types are: (1) brand communities (focus on users input to developing a specific company's product portfolio); (2) beta-test communities (focus on user tests of prototypes); (3) user content communities (focus on users contributing with content to innovative solutions); (4) development communities (focus on users developing products and services); and (5) innovation intermediary communities (focus on supporting innovation interactions between users and organisations). In this paper, the focus is an innovation intermediary community where users are invited to participate in innovation activities hosted by a neutral party. Hence, the users often do not know which company initiates the innovation process and they participate as private persons in their spare time. Implementing any kind of innovation community in an organisation, however, is not enough to succeed with a user innovation approach. It also is important to know what motivates users in these communities.

According to Lampel \& Bhalla (2007), much of the research concerning virtual communities has been focused on exploring the contrast between online communities and their real-world counterparts. In addition, much of the research has focused on understanding the drivers behind social interaction in these communities (Hars and Ou, 2002; Wasko and Faraj, 2000; Franke and Hippel, 2003). While these drivers are important to understand, they leave open the question of the nature of the users contributing to online innovation communities and how important certain motivators are for users' willingness to participate in these innovation communities' activities. Hence, the aim of this paper is to explore what motivates users to contribute voluntarily to innovation processes in an innovation intermediary community with the objective to guide organisations on how to utilise their innovation intermediary communities.

The subsequent section describes different types of innovation communities, followed by a presentation of users' motivation related to different types of innovation communities. Thereafter, our innovation intermediary community, Botnia Living Lab, is presented including a description of our methodology. Following that is a presentation of the findings from the study together with a discussion about for example, the homogeneity within the community and the heterogeneity across communities, and motivational factors. Finally, the conclusions that can be drawn from this study are presented. 


\section{Innovation Communities}

Applying an open user innovation community approach makes it possible for organisations to gain from encouraging their users to interact with each other as well as with the organisation. To facilitate user interaction, organisations are starting to view user innovation communities as strategic assets that give them access to external expertise, new ideas on innovation and support in the innovation development process (Desouza et al., 2008). For organisations that utilise user innovation communities, values such as an increase of their capacity to continuously update their competencies and adjust better towards the changing business environment has been identified (Di Gangi and Wasko, 2009).

As mentioned previously, many different forms of online innovation communities are available on the Internet today, aiming to facilitate open and user driven innovation in some way. Some of these communities are hosted by companies, others by neutral partners facilitating the innovation process and some are hosted by developers and users. In this paper, five types of innovation communities are described. These five types are: brand communities, beta-test communities, user content communities, development communities and innovation intermediary communities.

A brand community is a specialised, non-geographically bound community based on a structured set of social relationships among admirers of the brand (Muniz and O'Guinn, 2001). The implementation of brand communities can be seen at for example Audi, Nike and Harley Davidson, where users are invited to become part of the company's development and innovation process by contributing their ideas and modifications (Füller, Matzler, and Hoppe, 2008; Muniz and O'Guinn, 2001). The users of these brandor product communities often are passionate about the brand and have great experience of using the products (Füller, Matzler, and Hoppe, 2008); hence, they are a valuable asset to these communities.

In beta-test communities, users are invited to test often quite mature prototypes before they are launched at the market. These communities are driven primarily by a company developing its own products; examples of this type of communities are Nokia Beta Labs (Peltola, 2008), Dell IdeaStorm (Di Gangi and Wasko, 2009) and Google Labs. The purpose of beta testing is to allow real users to use the product and give feedback in relation to different aspects (Fine, 2002). In these beta test communities, the users often are early adopters with an interest to perform prototyping and testing. In these testing activities, there are both sparse interactions between users and the company, and among the members of the community.

The third type of innovation communities, the user content communities, is communities where users join a network with the aim to create content collaboratively. This phenomenon can be seen in, for example, Google Maps, YouTube and Wikipedia, where users jointly produce content for others to view and use. In these communities, there is no obvious difference between users, and their collaboration is built totally on their voluntary effort. The content users produce in these communities can take different forms, such as, for example, film, music and text. Hence, the users contribute and cocreate innovations by producing content and by commenting and rating others' content; thus, they do not create the innovations as such but these innovations would not succeed without the users' input.

When it comes to development communities, we refer mainly to open source communities and other developer communities where developers collaboratively develop a new IT product or service, such as, for example, Linux, Apache and Firefox (Barcellini, Détienne, and Burkhardt, 2008). These developers can meet at communities such as SourceForge.net and developer.android.com where they can submit, discuss and solve a 
problem in collaboration. In these networks, heterogeneous collaborative teams are formed with the aim to develop or improve open source software products together (Casalo, 2009). These networks also favour product distribution to a very broad audience at very low cost, often for free.

The fifth type of innovation communities, the innovation intermediary communities, has the role to act as mediators between different stakeholders such as users and companies (Antikainen, Mäkipää, and Ahonen, 2010). Examples of these communities are FellowForce, CrowdSpirit and Owela. In these communities, users are invited be involved in all phases of the innovation process on a voluntary basis, and the communities are hosted primarily by a neutral party. This means that the main difference between company-hosted communities and innovation intermediaries is that the users involved in these communities usually are not the companies' customers, and there is no strong relationship between the users and the company (Antikainen, Mäkipää, and Ahonen, 2010). The contributing users in these innovation intermediaries often are given monetary rewards for their efforts, and this type of community is the focus for this paper.

\section{User Motivation in General}

When it comes to users and their motivation to participate and contribute to these communities, the basic principle is that motivation is based on the goals, or ends, that people try to reach with their current activity. The idea with end motives has a long tradition and goes back to Aristotle, who divided motives into ends and means (Reiss, 2000). An end motive is something people enjoy for their own sake, whereas the means are the methods or tools that are used to satisfy the end motives. This implies that means are the steps that are taken on the way to fulfil an end motive. The number of means that can be used to reach the end motive is limited only by fantasy, while the end motives are genetically limited (Reiss, 2001). The satisfaction of an end motive gives rise to a specific feeling of joy, but soon after an end motive has been satisfied, the feeling of joy dissipates and the desire to fulfil it reasserts itself (Reiss, 2005, 2004).

One common approach when it comes to motivation is to make a distinction between intrinsic and extrinsic motivation (Leimeister et al., 2009). Intrinsic motivation occurs when an individual engages in an activity, such as a hobby, that is initiated without obvious external incentives. This type of motivation refers to the desire to feel competent and self-determined. External motivation is activated by external incentives, such as direct or indirect monetary compensation, or recognition by others (Hars and Ou, 2002). Both these motivational factors might be of importance to the user's decision to take part in the innovation community's activities. For example, some users might be motivated by the competitive factors if the community arrange an idea competition, while other users might be externally motivated by the possibility to win a prize of monetary value, or being intrinsically motivated by the opportunity to have fun while competing (Leimeister et al., 2009).

\subsection{User Motivation in Innovation Communities}

When it comes to user motivation related to innovation communities in particular, von Hippel (von Hippel, 2001) found that innovations communities are most likely to flourish when three conditions are met: (1) some users have sufficient incentives to innovate; (2) some users have incentives to voluntarily reveal their innovation; (3) userdriven diffusion of innovation can compete with commercial products. This refers to user innovation communities in general which means that these communities can either be 
supported by IT tools or mainly focus on face-to-face meetings. It is argued that the same motivation takes different shape in online communities because it is articulated under different conditions (Lampel and Bhalla, 2007). Hence, it is interesting to gain insights about what motivates users in online communities in particular.

Related to that, Antikainen, Mäkipää \& Ahonen (2010) have performed a literature study about what motivates user to participate in online communities in general. Their study revealed sixteen motivating factors: altruism, care for the community, enjoyment, firm recognition, friendship, ideology, interesting objectives and intellectual stimulations, knowledge exchange, monetary rewards, need, peer recognition, reciprocity, recreation, reputation, sense of efficacy, and a sense of obligation to contribute (Antikainen, Mäkipää, and Ahonen, 2010). These factors are important to consider, but they do not distinguish what motivates users in a particular type of community nor do they focus on innovation communities in particular.

Due to the diversity of innovation communities, it can be suspected that users' motivations for contributing and participating in these communities differ depending on which type of community they are engaged in; see table 1.

Table 1: Motivation and community types

\begin{tabular}{|c|c|c|}
\hline $\begin{array}{l}\text { Type of } \\
\text { community }\end{array}$ & Motivator & Authors \\
\hline \multirow{3}{*}{ Brand community } & Interest in innovation activities & (Füller, Matzler, and Hoppe, 2008) \\
\hline & Creative personality & (Füller, Matzler, and Hoppe, 2008) \\
\hline & Wish to be recognised by the firm & (Jeppesen and Frederiksen, 2006) \\
\hline \multirow{6}{*}{$\begin{array}{l}\text { Developer } \\
\text { community }\end{array}$} & $\begin{array}{l}\text { Reputation building/recognition } \\
\text { for contribution }\end{array}$ & (Casalo, 2009) \\
\hline & $\begin{array}{l}\text { Satisfaction of members needs } \\
\text { and interest }\end{array}$ & (Casalo, 2009) \\
\hline & Reciprocity, altruism & (Wasko and Faraj, 2000; Hars and Ou, 2002) \\
\hline & $\begin{array}{l}\text { Expected future rewards, benefits } \\
\text { exceeds costs }\end{array}$ & $\begin{array}{l}\text { (Franke and Hippel, 2003; Hars and Ou, } \\
\text { 2002) }\end{array}$ \\
\hline & Knowledge exchange and learning & (Wasko and Faraj, 2000; Hars and Ou, 2002) \\
\hline & Benefits exceeds costs & (von Hippel, 2001) \\
\hline \multirow{5}{*}{$\begin{array}{l}\text { Beta-test } \\
\text { community }\end{array}$} & Altruism & (Peltola, 2008) \\
\hline & Curiosity & (Peltola, 2008) \\
\hline & Making a difference & (Peltola, 2008) \\
\hline & Being a forerunner & (Peltola, 2008) \\
\hline & Satisfying a specific need & (Peltola, 2008) \\
\hline \multirow{4}{*}{ User content } & Enjoyment and fun & (Nov, 2007) \\
\hline & Status seeking & (Lampel and Bhalla, 2007) \\
\hline & Altruism & (Lampel and Bhalla, 2007) \\
\hline & Reciprocity & (Lampel and Bhalla, 2007) \\
\hline \multirow{2}{*}{$\begin{array}{l}\text { Innovation } \\
\text { intermediary }\end{array}$} & Monetary rewards & (Antikainen and Väätäjä, 2008) \\
\hline & Recognitions for ideas & (Antikainen and Väätäjä, 2008) \\
\hline
\end{tabular}


In this table, we have summarised different motivators related to a specific type of community. It is noticeable that users' motivation differs between innovation community type. For instance, in brand communities, users are motivated to participate by a wish to get recognised by the firm. In addition, in both developer communities and user content communities, users are motivated by status seeking, reciprocity and altruism, while this is not as obvious in brand communities and innovation intermediary communities. Our study, which is rather limited in scope; should be considered as one step towards an understanding of users' motivation in relation to different innovation communities. In our review we have found that many studies are focused on open source communities, with one plausible reason for this perhaps being that this type of communities has existed for several years with good results. There is thus a need for more studies focusing on user motivation in other types of emerging innovation communities.

\section{Our Innovation Intermediary Context - Botnia Living Lab}

In this study we focus on an innovation intermediary milieu that is called Botnia Living Lab. Botnia is an R, D \& I joint venture between core partners with the objective to generate sustainable business innovations. The Botnia Living Lab milieu, launched in 2003, is an online community in which users can contribute to the innovation process by taking an active part in the development and test of ideas, mobile and stationary services, and products such as mobile phones, computers and games.

In short, Botnia Living Lab is a gathering of public and private partnerships where companies, researchers, government and users work together for the creation, validation and test of new services, business ideas and technologies in real-life contexts (BergvallKåreborn and Ståhlbröst, 2009; Ståhlbröst, 2008). In this milieu, registered users are invited to participate in the development of different technologies by, for example, participating in idea generation activities, concept development and evaluation and test of innovative technology in the users' everyday context.

When users are involved in Botnia's activities, the aim is to involve them in the whole development process. The endeavour is to involve users in their natural environment by means of technology, with the objective to gain access to users' needs, ideas and attitudes in their current situation. Due to Botnia's focus on products and services to support a mobile life, the circumstances in which the user involvement processes are conducted become multi-contextual in character. This means that the users can be involved, for example, in their homes, when they walk around the city, when they drive a car or when they work.

\section{Methodology - Data Collection}

In this study, we have used an online survey to collect data from the users. This survey was publicised by contacting a significant number (n2545) of users in Sweden during the spring of 2010 via e-mail. These users are gathered in a user database at Botnia Living Lab, which has been built up since year 2003. The aim of this database is to create a gateway to users who are willing to take part in innovation activities on a voluntary basis. This particular study was introduced to the participants as a self-reporting opinion survey regarding "Your participation in innovation activities". The survey drew responses from 270 users, which gave us a response rate of $10.6 \%$. One plausible reason for the low response rate can be that many of the invited users are involved only occasionally in 
Botnia Living Lab activities; hence, they might not feel qualified to answer. Getting answers from all of these users could have been valuable since these users' perspectives might have rendered a different view on motivation to participate in innovation activities. However, the aim of the study was to get response from the users who want to be, have been or are involved in innovation activities; thus, the users who did not respond might be outside our scope of interest.

In this study, the question framework was based on the literature study concerning users and motivators in different types of communities. The framework has not been tested and validated in other studies; hence, the results from this study need to be validated in additional studies. Our survey consisted of five question areas: background questions (demographic characteristics such as gender, education etc.,), Internet usage habits, technology adoption type, and motivation for participating in innovation activities in the community. In this paper, we will explore users' motivation for participating in an innovation intermediary community.

\section{Findings}

The following section gives the findings regarding the users, community use characteristics, Internet and social media usage, technology adoption type and motivational factors.

\subsection{The users}

Analysing the background data of the respondents, see table 2, we find that two-thirds are male and one third female. Despite this difference, the distribution in gender comes close to the common scale of 40/60 often seen as the threshold of gender equality. The age of the respondents ranges between 15-68 years old, with $29 \%$ of the respondents between $31-40$ years old and $71 \%$ between the ages of $26-50$. Half of the respondents have a university degree and almost $70 \%$ are employed.

Table 2. Demographic characteristics

\begin{tabular}{lccc}
\hline \multicolumn{2}{l}{ Demographic characteristics } & Frequency (n) & Percentage (\%) \\
\hline \multirow{2}{*}{ Age } & & & \\
& $15-20$ & 4 & 1.5 \\
& $21-30$ & 78 & 29.0 \\
$31-40$ & 78 & 29.0 \\
$41-50$ & 66 & 24.5 \\
$51-65$ & 32 & 12.0 \\
$66-$ & 4 & 1.5 \\
Unusable data & 7 & 2.5 \\
\hline \multirow{2}{*}{ Gender } & & \\
Male & 178 & 66.0 \\
Female & 92 & 34.0 \\
\hline
\end{tabular}




\begin{tabular}{lcc}
\hline Education & & \\
Elementary school & 14 & 5.0 \\
2 years education & 49 & 18.0 \\
3 years education & 74 & 28.0 \\
University education & 124 & 46.0 \\
Research education & 8 & 3.0 \\
\hline Main occupation & & \\
Senior high school student & 4 & 1.5 \\
University student & 30 & 11.0 \\
Employed & 183 & 68.0 \\
Company owner & 15 & 5.5 \\
Retired & 11 & 4.0 \\
Unemployed & 14 & 5.0 \\
\hline
\end{tabular}

\subsection{Community use characteristics}

Even though the community is directed towards private persons and hence voluntary use, few respondents, $4 \%$, state they participate as part of their work; see table 3 . Of these, all are male.

The majority of the respondents, almost $60 \%$, have been community members for several years, which indicates a strong loyalty and commitment to the community. What can be seen as unanticipated is the large number of respondents, almost $20 \%$, who do not know how long they have been a member. Linking this to gender, we see a clear divide in relation to the long time members; $28 \%$ of all women and $68 \%$ of all men have been a member for several years. That is, for the male respondents, the majority have been part of the community for several years while only a third of the women respondents are longtime members. For all other categories, the women are in majority. This indicates that the number of new female members has increased over the last year, and if this trend continues, the relation between male and female members is slowly evening out. There can be many reasons for this change. One possible external reason can be the maturity of the technology; communities no longer are considered high tech and directed towards technological geeks, but directed to the "Smiths" of the world.

When it come to the intensity of the respondent's involvement in community activities this is relatively evenly spread between zero and more than ten. Around $40 \%$ have participated in three or more studies, while just over $30 \%$ have participated in zero to two studies. Here, no big difference can be seen between genders. The largest single group represents respondents who do not know how many studies they have participated in. However, in relation to this question, it is easier to speculate on possible reasons since the alternatives are much closer to each other. 
Table 3. Community use characteristics

\begin{tabular}{lcc}
\hline Community use characteristics & Frequency (n) & Percentage (\%) \\
\hline Duration of participation in the community & & \\
A few weeks & 10 & 4 \\
A few months & 26 & 10 \\
Approximately one year & 28 & 10 \\
Several years & 155 & 57 \\
Do not know & 50 & 18 \\
\hline Amount of user innovation involvement activities & & \\
None & 36 & 13 \\
1-2 & 50 & 18 \\
3-5 & 41 & 15 \\
6-10 & 30 & 11 \\
More than 10 & 44 & 16 \\
Do not know & 68 & 25 \\
\hline Involvement Role & & \\
As a part of the occupation & 11 & 5 \\
As a private person & 256 & 95 \\
\hline
\end{tabular}

Since about $60 \%$ of the respondents have been members of the community for several years and the categories of answering alternatives are quite narrow and close to each other, the question requires quite exact answers to activities that can have occurred over a long period. Despite this, the data show that the majority of the respondents have participated in more than one study and as such can be seen as returning users of the community.

\subsection{The users' technology adoption type}

When it comes to technology adoption type, the aim was to get a view of how the respondents adopt new technology; see table 4 below. The definition of the different adoption types were:

- Innovator: A soon as I, or others in my surrounding, have a need of a new technological application or service, I develop it myself.

- Visionary: I often have ideas for, or discover that I have a need for, a new product and service before they are available at the market.

- Technology enthusiast: As soon as a new product or service is available at the market, I want to start using it.

- Utility users: When I realise that a new technical product or service is useful via a few people in my surrounding who use it, I also start to use it.

- Technology conservative: When a new technical product or service has been available at the market for a long period of time and most people in my surrounding use it, I usually start using it.

- Technology sceptical: I am sceptic towards new technology and it often takes a long time before I start using new technological products or services. 
Table 4. Technology adoption type

\begin{tabular}{lccccc}
\hline Innovator & Visionary & $\begin{array}{l}\text { Technology } \\
\text { enthusiast }\end{array}$ & Utility users & $\begin{array}{l}\text { Technology } \\
\text { conservative }\end{array}$ & $\begin{array}{l}\text { Technology } \\
\text { sceptical }\end{array}$ \\
\hline $11(4.35 \%)$ & $40(15.8 \%)$ & $96(38 \%)$ & $92(36.5 \%)$ & $13(5.15 \%)$ & 0 \\
\hline
\end{tabular}

Here we can see that most of the users in this study perceive themselves as being technology enthusiasts (38 \%) or utility users (36.5\%), while none of them are sceptical towards new technology. This corresponds well with the users' high use of the Internet and social network presented in the section below.

\subsection{The users' internet and social media use}

When it comes to Internet use, the respondents show a very high level of use; see table 5 below. Almost everybody, 97\%, use the Internet either 24/7 or several times a day, and the two groups are almost equal in size. However, viewing the two use levels from a gender perspective, we see that $51 \%$ of all men use the Internet $24 / 7$ while only $25 \%$ of all women do the same.

Table 5. The users' Internet and social media use

\begin{tabular}{|c|c|c|}
\hline Users personal characteristics & Frequency (n) & Percentage (\%) \\
\hline \multicolumn{3}{|l|}{ Internet usage } \\
\hline Connected $24 / 7$ & 113 & 43.4 \\
\hline Several times/day & 139 & 53.4 \\
\hline Once/day & 6 & 2.3.0 \\
\hline A few times/week & 0 & 0 \\
\hline A few times/month & 2 & 0.76 \\
\hline \multicolumn{3}{|c|}{ Members of social networks (like Facebook) } \\
\hline Yes & 217 & 83.5 \\
\hline No & 42 & 16 \\
\hline Do not know & 1 & 0.5 \\
\hline \multicolumn{3}{|l|}{ Number of social networks } \\
\hline $1-3$ & 181 & 81 \\
\hline $4-6$ & 35 & 15.5 \\
\hline $7-9$ & 5 & 2 \\
\hline$>10$ & 3 & 1.5 \\
\hline \multicolumn{3}{|l|}{ Frequency of use of social network } \\
\hline $24 / 7$ & 34 & 15 \\
\hline Several times a day & 103 & 46 \\
\hline Once a day & 35 & 15.5 \\
\hline A few times a week & 37 & 16.5 \\
\hline A few times a month & 11 & 5 \\
\hline More seldom & 5 & 2 \\
\hline
\end{tabular}


The vast majority of users, $83.5 \%$, also are members of one or several social networks, such as Facebook. Of these, 81\%, are members of one to three social networks, while $15 \%$ are members of between four to six networks. More than $90 \%$ of the respondents visit their social networks at least a few times a week, while more than $60 \%$ visit them several times a day or 24/7.

In our survey, we also wanted to get some insights into what type of activities the users usually used on the Internet. This was a seven graded Likert scale question, where 1 referred to Never and 7 referred to Several times a day. Related to what the users mainly use the Internet for several times a day, $68.8 \%$ of the users answer that they use it to check their e-mails, 50.3\% search for information, 36.5\% communicate with their friends, and $36.5 \%$ read news.

When it comes to what they never use the Internet for, $52.3 \%$ never play online games, 58.8\% never develop applications, 69.2\% never author their own blogs, and $58.8 \%$ never publish content on sites such as YouTube and Flickr. The data regarding the users' social media behaviour clearly indicate that the social factor of the media attracts users most, such as catching up and communicating with existing friends as well as sharing experiences and pictures with their personal network. What can seem as surprising is the fact that activities that are closely related to Botnia Living Lab activities, such as answering questionnaires and testing new products and services, are ranked relatively low.

Table 6. Social media behaviour

\begin{tabular}{lcc}
\hline Social media behaviour & Frequency (n) & Percentage (\%) \\
\hline Read about what friends do or have done & 192 & 71 \\
Look at people's pictures & 137 & 51 \\
Direct communication with friends (like chat) & 129 & 48 \\
Comment others pictures, logs, etc. & 108 & 40 \\
Search for information & 102 & 38 \\
Show personal pictures & 78 & 29 \\
Write in a personal log & 58 & 22 \\
Test new products and services & 54 & 19 \\
Answer questionnaires & 52 & 19 \\
Actively participate in discussion forums & 52 & 19 \\
Play games & 51 & 18 \\
Carry out different tests & 49 & 16 \\
Search for new friends & 44 & 14 \\
Create or participate in groups & 39 & 20 \\
\hline
\end{tabular}

\subsection{The user's motivational factors}

Regarding the user's motivation for participating in innovation activities, our questions stem from the literature review on community motivation. The results from this question are presented in table 7 below. The question was formulated as: How important would it be for you that your participation... and then the different constructs were presented. In these questions, the constructs were measured using multiple items, which were gathered in the survey using a seven-level Likert scale where 7 represents Very important and 1 represent Not at all important. The constructs were adapted primarily from previous literature, such as Antikainen et al. (2010), but modified to request data on 
the specific innovation intermediary community. In the table below, the motivators and the response rate are described.

Based on the users' answers, six motivators stand out as most important for them. Here we chose to discuss the motivators with the highest means, above and close to 5 . These motivators are learn something new, stimulate curiosity, testing innovative products and services, testing products and services that are new to the user and having a possibility to win something. The motivators the users consider as least important for their participation in innovation community activities are getting to know new people, feel a social belonging, winning something and sharing experience with others. These motivators had a mean score close to 4; hence, they are not considered as unimportant but they are least important in this study.

Table 7. The users' motivational factors

\begin{tabular}{lccc}
\hline Users' motivational factors & Mean & Low (1-2) & High (6-7) \\
\hline Getting a needed innovation & 4.87 & 11.5 & 41 \\
Stimulating curiosity & 5.63 & 2.8 & $\mathbf{5 9 . 1}$ \\
Contributing with ideas to innovations & 4.86 & 10.3 & 36,9 \\
Giving vent to creativity & 4.98 & 7.5 & 39.7 \\
Is experienced as positive by other & 4.95 & 13.9 & 34.2 \\
Being the first to test an innovation & 4.91 & 11.5 & 44 \\
Being entertained & 5.26 & 6.4 & $\mathbf{5 0 . 6}$ \\
Feeling that my opinion is important & 4.64 & 11.1 & 32.2 \\
Making a better society & 4.77 & 7.9 & 34.1 \\
Testing products and services & 5.56 & 3.6 & $\mathbf{5 9 . 2}$ \\
Testing technical solutions that are new to me & 5.42 & 6 & $\mathbf{5 5 . 2}$ \\
Learning something new & 5.83 & 2.4 & $\mathbf{6 9}$ \\
Social belonging & 4.18 & $\mathbf{1 7 . 9}$ & 22.6 \\
Sharing experiences with others & 4.57 & 10.3 & 27.8 \\
Getting to know new people & 4.01 & $\mathbf{2 2 . 6}$ & 21.4 \\
Winning something & 4.56 & $\mathbf{2 1 . 7}$ & $\mathbf{5 3 . 5}$ \\
\hline
\end{tabular}

\subsection{Findings technology adoption type and motivation}

When it comes to technology adoption type and which aspects are important to motivate them to participate, a clustering was made of the answers referring to 6-7 on the Likert scale from the two main technology adoption types, utility users and technology enthusiasts. The selection of these two categories is based on the users' responses since $74.5 \%$ of the users fall within these categories. This clustering revealed that the same five motivators are considered as important, but the number of users grouping themselves to one factor differ, as shown in table 8 below.

In this table, the motivators the utility users consider as most important are: learning something new, testing innovative products and service, testing products and services that are new to the users, stimulating curiosity and being entertained. The technology enthusiasts were motivated mainly by learning something new, stimulating curiosity, testing innovative products and services, testing products and services that are new to the user, and being entertained. 
Table 8: Technology adoption type and motivational factors

\begin{tabular}{|c|c|c|c|}
\hline $\begin{array}{l}\text { Technology } \\
\text { adoption } \\
\text { type } \\
\end{array}$ & Motivator & Mean score & $\begin{array}{c}\text { Percentage of } \\
\text { type (\%) }\end{array}$ \\
\hline \multirow{5}{*}{ Utility User } & Learn something new & 6 & 62 \\
\hline & Test innovative products and services & 5 & 46 \\
\hline & Stimulate curiosity & 5 & 43 \\
\hline & Test products and services that are new to the user & 5 & 43 \\
\hline & Be entertained & 5 & 41 \\
\hline \multirow{5}{*}{$\begin{array}{l}\text { Technology } \\
\text { enthusiast }\end{array}$} & Learn something new & 6 & 81 \\
\hline & Stimulate curiosity & 6 & 73 \\
\hline & Test innovative products and services & 6 & 72 \\
\hline & Test products and services that are new to the user & 6 & 68 \\
\hline & Be entertained & 6 & 62 \\
\hline
\end{tabular}

\section{Discussion}

In this paper, we have found that many aspects must be considered to understand the nature, and to harvest the potential, of innovation community users. One thing we consider as important to stimulate user engagement is to understand the characteristics and motivators of the users in an innovation community. In our study, we have focused on understanding users of an innovation intermediary community and how important certain factors are for their motivation to participate in innovation activities.

\subsection{The homogeneity within the community and the heterogeneity across communities}

Our data clearly show that the users of Botnia Living Lab have many common characteristics. They all have a high technological use level; 97\%, use the Internet either $24 / 7$ or several times a day; $83.5 \%$ are members of one or several social networks and more than $60 \%$ of them visit their networks several times a day or 24/7. The users' attitudes about technology also are confirmed by their choice of technology adoption type. None of the users sees themselves as technology sceptics; instead, the majority viewed themselves as either technology enthusiasts or utility users. There also is a high representation of people at university, with a university degree or employed. The main difference in the group is related to age and gender.

The picture becomes a bit more diverse when we analyse what motivates the members of Botnia LL to participate in innovation projects. As is illustrated in table 7, there are five motivational factors that are ranked as very important by more than half of the user group: learning something new, testing innovative products and services, curiosity, winning something, and being entertained. This means that the group as a whole is in consensus that these motivational factors are important; the divergence in their answers is rather about how important the factors are considered. The same trend can be seen among the other factors as well.

Learning something new is the strongest motivational factor within the group; it is seen as important to almost everybody, and very important to almost $70 \%$ of the users. Among the top six motivational factors, only one divides the group in two camps and this 
is related to the importance of being able to win something. While the majority of the users state that they are strongly motivated by the possibility to win something, more than $20 \%$ of the users also state that this is not at all important. As such, it represents one of the few motivational factors listed that more than $15 \%$ of the users considers as not at all important.

It also is interesting to see that two of the three motivational factors ranked as least important by the users relate to social factors: getting to know new people and social belonged. This is somewhat surprising considering the users' relatively high involvement in social networks. One possible explanation for this is that different types of communities satisfy different needs for the users. Hence, social networks are used mainly to satisfy socially related needs while Botnia Living Lab, as an innovation intermediary community, satisfies needs related to learning, testing innovative products and services, and stimulating curiosity.

Since user communities and innovation communities have become a way for organisations to utilise external resources, they appear in many different contexts and form, and as such they differ in purpose, methods, user profile, etc. Developer communities such as Free/Libre and Open-Source Software communities (FLOSS) are characterised by young single male developers without children but with a university degree with a technical orientation (David and Shapiro, 2008). They mainly are motivated by values such as: people should be free to software they use; I want to give back to the community, and I want to provide alternatives to proprietary software (ibid).

Developer communities for mobile applications, such as those hosted by Apple and Google, attract similar groups of people as FLOSS but the motivational drivers differ. For these developers, the size of the market, return on investments, low barriers and personal development are main motivational factors (Bergvall-Kåreborn et al., 2010). For these users, the brands of Apple and Google, and what they stand for, also are of vital importance.

This, together with the discussion in section 3.1, indicates that there are major differences between categories of innovation communities, as well as within. It also points to the dangers of clustering diverse communities together and treating the users and their motivational factors as homogeneous, as often is done in literature (e.g. Antikainen, Mäkipää, and Ahonen, 2010; Lampel and Bhalla, 2007; Dholakia, Bagozzi, and Pearo, 2004).

\subsection{Technology adoption types and their motivational factors}

The previous section included a discussion of the most important motivational factors for users in the innovation intermediary community. Dealing with motivational factors is not a straightforward process where one size fits all; instead, it is dependent on situational and personal factors. In research related to different personality types, it has been found that individual personality traits play a role in the use of interactive social media tools (Ross et al., 2009; Correa, Hinsley, and de Zúñiga, 2010). Since a specific personality type leads to a diversity of usage, it can be expected that a specific technology adoption type might influence the motivational factors for users to contribute to innovation activities.

The findings from our study show that the two technology adoption types, utility user and technology enthusiasts, view the same motivators as important, but to a somewhat different degree. The utility users tend to be more careful to take a clear stand on what they view as very important for their motivation to participate. Hence, the utility users seem to feel that all the motivational factors are important to a lower degree than the technology enthusiasts do. In addition, the technology enthusiasts think that stimulating 
curiosity is more important than the utility users. One possible reason for this can be that the nature of the technology enthusiasts inherits an interest of new things and, hence, stimulating their curiosity becomes important. For the utility users, this might take the form of being careful to take a clear standpoint, which is in their nature of wanting to know a value of something before they act. Based on that, we can see that users' technology adoption type might influence what motivates them to participate in innovation community activities, but in this study it has not been validated to what extent this is true. Hence, more research on technology adoption type and motivation are needed.

\section{Conclusion}

The purpose of this paper was to explore what motivates users to participate in innovation activities in an innovation intermediary context. Understanding users' motivation is a challenging task which is highly dependent on situational factors. When it comes to the motivators as such, this study confirms earlier studies on user motivation in innovation communities in general (e.g. Antikainen, Mäkipää, and Ahonen, 2010), and it also adds to the understanding of what motivates users in innovation intermediary communities in particular. This study illustrates that the most important motivators for users' participation are intrinsic motivations such as learning, stimulating curiosity and being entertained. The motivator being rewarded for their participation in innovation intermediaries also have been identified in other studies (Antikainen and Väätäjä, 2008), but this was not among the most important motivators in this study. In contrast to Antikainen and Väätäjä (2008) our study does not show that getting recognised for ideas is especially motivating for the users in this type of community. Motivators such as feeling social belonging or getting to know new people are not considered as important, which might imply that these needs are stimulated in other contexts, such as social networking sites.

In the literature study presented in this paper, a noticeable difference among motivational factors in the categories of innovation communities was discovered, as well as different usages of a specific type of community. In this study we have identified two aspects which influence users' motivation from an overarching perspective. These aspects are type of innovation community and the users' technology adoption type. Different communities fulfil different goals for diverse types of users; hence, they have different expectations, engagement and intentions with their participation in different communities. Thus, to fully harvest the potential of a community, it is important to understand what is important for the users in that specific context and make sure that this is fulfilled.

\section{References and Notes}

Antikainen, M. Mäkipää, M. and Ahonen, M. (2010). Motivating and supporting collaboration in open innovation. European Journal of Innovation Management, Vol. 13, No. 1, pp.100-119.

Antikainen, M. and Väätäjä, H. (2008). Rewarding in open innovation communities how to motivate members? In ISPIM.

Barcellini, F.,Détienne, F. and Burkhardt, J.-M. (2008). User and developer mediation in an open source software community: Boundary spanning through cross participation in online discussions. International Journal of Human-Computer Studies, Vol. 66, No. 7, pp.558-570. 
Bergvall-Kåreborn, B.,Björn, M.,Chincholle, D.,Hägglund, C.,Larsson, S. and Nyberg, M., (2010). The pioneers of mobile application development - a silhouette of android and iphone developers. Paper read at Proceeding of the ISPIM conference, at Bilbao, Spain, 1027,

Bergvall-Kåreborn, B. and Ståhlbröst, A. (2009). Living Lab - an open and citizen-centric approach for innovation. International Journal of Innovation and Regional Development, Vol. 1, No. 4, pp.356-370.

Casalo, L. V. (2009). Determinants of success in open source software networks. In Industrial Management \& Data Systems, edited by Cisneros, J.Flavian, C. and Guinaliu, M.

Correa, T.,Hinsley, A. W. and de Zúñiga, H. G. (2010). Who interacts on the web? The intersection of users' personality and social media use. Computers in Human Behavior, Vol. 26, No. 2, pp.247-253.

David, P. A. and Shapiro, J. (2008). Community-based production of open-source software: What do we know about the developers who participate? . Information Economics and Policy, Vol. 20, No. 4, pp.364-398.

Desouza, K., C.,Awazu, Y.,Jha, S.,Dombrowski, C.,Papagari, S.,Baloh, P. and Kim, J. (2008). Customer-driven innovation - to be a marketplace leader, let your customers drive Research Technology Managment, Vol. 5, No. 3, pp.35-44.

Dholakia, U. M.,Bagozzi, R. P. and Pearo, L. K. (2004). A social influence model of consumer participation in network- and small-group-based virtual communities. International Journal of Research in Marketing, Vol. 21, No. 3, pp.241-263.

Di Gangi, P. M. and Wasko, M. (2009). Steal my idea! Organizational adoption of user innovations from a user innovation community: A case study of Dell Ideastorm. Decision Support Systems, Vol. 48, No. 1, pp.303-312.

Fine, M., . R. (2002). Beta testing for better software. New York: Wiley Computer Publishing.

Franke, N. and Hippel, E. v. (2003). Satisfying heterogeneous user needs via innovation toolkits: The case of apache security software. Research Policy, Vol. 32, No. 7, pp.1199-1215.

Füller, J.,Matzler, K. and Hoppe, M. (2008). Brand community members as a source of innovation. Journal of Product Innovation Management, Vol. 25, No. 6, pp.608619.

Hars, A. and Ou, S. (2002). Working for free? Motivations for participating in opensource projects. International Journal of Electronic Commerce, Vol. 6, No. 3, pp.25-39.

Jeppesen, L. and Frederiksen, L. (2006). Why do users contribute to firm-hosted user communities? The case of computer-controlled music instruments. Organizational Science, Vol. 17, No. 1 january-February, pp.45-63.

Lampel, J. and Bhalla, A. (2007). The role of status seeking in online communities: Giving the gift of experience. Journal of Computer-Mediated Communication, Vol. 12, No. 2, pp.434-455.

Leimeister, J., M. „Huber, M.,Bretschneider, U. and Helmut, K. (2009). Leveraging crowdsourcing: Activation-supporting components for IT-based ideas competition. Journal of Management Information Systems, Vol. 26, No. 1, pp.197-224.

Muniz, A. and O'Guinn, T. (2001). Brand community. Journal of Consumer Research, Vol. 27, No. March 2001, pp.412-432.

Nov, O. (2007). What motivates Wikipedians. Communication of the ACM, Vol. 50, No. 11, pp.60-64.

Peltola, I. (2008). Online co-creation and beta trialling of mobile software and srvices, Faculty of Business and Technology Management, Tampere University of Technology, Tampere. 
Reiss, S. (2000). A mindful approach to mental retardation. Journal of Social Issues, Vol. 56 , No. 1, pp.65-80.

Reiss, S. (2001). Vem är du? De 16 basbehoven som styr våra handlingar och bestämmer vår personlighet. Translated by Sellin, A. Stockholm: Svenska förlaget.

Reiss, S. (2004). Multifaceted nature of intrinsic motivation: The theory of 16 basic desires. Review of General Psychology, Vol. 8, No. 3, pp.179-193.

Reiss, S. (2005). Human individuality and the gap between science and religion. Zygon, Vol. 40, No. 1, pp.131-142.

Ross, C.,Orr, E. S.,Sisic, M.,Arseneault, J. M.,Simmering, M. G. and Orr, R. R. (2009). Personality and motivations associated with Facebook use. Computers in Human Behavior, Vol. 25, No. 2, pp.578-586.

Ståhlbröst, A. (2008). Forming future IT - the Living Lab way of user involvement, Department of Business Administration and Social Sciences, Luleå University of Technology, Luleå.

Wasko, M. and Faraj, S. (2000). It is what one does: Why people participate and help other in electronic communities of practice. Journal of Strategic Information Systems, Vol. 9, No. 23, pp.155-173.

von Hippel, E. (2001). Innovation by user communities: Learning from open-source software. MIT Sloan Management Review, Vol. Summer 2001, No., pp.82-86. 